\title{
ANTI-CYCLIC CITRULLINATED PEPTIDE ANTIBODIES VERSUS ANTI-MUTATED CITRULLINATED VIMENTIN ANTIBODIES IN JUVENILE IDIOPATHIC ARTHRITIS
}

\author{
By

\section{Mohamed Adly Khoudary Zeidan, Ahmed Mohammed Abd El-Rahman \\ Tahoun, Tarek Abd El-Kareim El-Dahshan, Abd Al-Hamid Abd Al- Hareth Ghazaly* and Ahmed Mohsen Abd El-Hakeem**}

Departments of Clinical Pathology, Rheumatology and Rehabilitation and Pediatrics, Faculty of Medicine, Al Azhar University, Cairo

Mobile: 01127399955, E-mail: dr.mohamedadly11@gmail.com

\begin{abstract}
Background: Juvenile idiopathic arthritis (JIA) is the most common chronic rheumatic disease in childhood and is of unknown etiology. Anti-cyclic citrullinated peptide antibodies (Anti CCP) and anti-mutated citrullinated vimentin antibodies (Anti MCV) may help in diagnosis of JIA.
\end{abstract}

Objective: Measurement of anti CCP and anti MCV level in JIA patients, and healthy persons to assess its possible role in diagnosis.

Patients and methods: This study included 70 patients with JIA, and 20 healthy volunteers with matched age and sex. We assessed serum anti CCP and anti MCV level in both groups by enzyme linked immunosorbent assay (ELISA). This study carried out over a period from July, 2019 to December, 2019.

Results: Serum anti-CCP and anti-MCV level showed a statistical significant difference between control and patient groups.

Conclusion: Anti-CCP as well as anti-MCV antibodies may be helpful in the diagnosis of JIA and should clearly be taken into consideration.

Key words: JIA, Anti CCP, Anti MCV.

\section{INTRODUCTION}

Disease onset prior to the age of 16 years and arthritis persisting for more than 6 weeks are required criteria for diagnosis of JIA (Giancane et al., 2016).

There are seven categories of JIA as defined by International League of Associations for Rheumatology (ILAR) classification criteria: Systemic onset JIA, rheumatoid factor negative Polyarticular JIA, rheumatoid factor positive polyarticular JIA, oligoarticular JIA, enthesitis-related arthritis, psoriatic arthritis and unclassified arthritis (Foeldvari, 2015).

Citrullination is a normal physiological form of post-translational modification in which arginine residues are changed to citrulline. This modification is mediated by enzymes called peptidylarginine deaminases (PADs) which primarily 
derived from neutrophils (Willis et al., 2017).

Anti-CCP is an autoantibody produced when the patient's immune system attacks its own body. Anti-CCP is used as a diagnostic marker for rheumatoid arthritis but now studies are going on to establish its role in other autoimmune diseases, even without arthritis (Bandana et al., 2017).

Post-translationally modified and native forms of vimentin are involved in the pathogenesis of inflammation and many autoimmune diseases, e.g. rheumatoid arthritis, sarcoidosis, systemic lupus erythematosus, antiphospholipid syndrome, Crohn's disease and ankylosing spondyloarthritis (Musaelyan et al., 2018).

Lipinska et al. (2016) indicated that anti-MCV as well as anti-CCP antibodies may be helpful in the diagnosis of JIA, especially in the early course of the disease. Anti-MCV antibodies could identify a group of children with JIA which is negative for anti-CCP antibodies and RF.

The aim of this study was to measure serum anti-CCP and anti-MCV level in JIA patients and healthy controls to assess their possible role in the diagnosis.

\section{PATIENTS AND METHODS}

This study was a cross sectional case control study and was approved by the Research Ethical Committee. Oral and written consents were obtained from all patients and controls after a full explanation of the study.

This study included ninety subjects with their ages ranging between 6-16 years. Subjects were classified into:
1. Control group: Included 20 apparently healthy individuals (not affected by any comorbidity and not treated with any medications at the time of study recruitment) with matched age and sex.

2. Patient group: Included 70 JIA patients which were recruited from Rheumatology and Rehabilitation Department at Al-Hussein University Hospital and Bab Al-Shaarya University Hospital during the period from July, 2019 to December, 2019. They were classified into two equal subgroups:

Group 1 A: Patients with polyarticular JIA. They were 10 males and 25 females.

Group 1 B: Patients with oligoarticular JIA. They were 15 males and 20 females.

\section{Inclusion criteria:}

1. Children with JIA.

2. Oligoarticular and polyarticular subtypes of JIA.

3. Age varied from 6 to 16 years old.

\section{Exclusion criteria:}

1. Subtypes of JIA other than oligoarticular and polyarticular.

2. Other autoimmune diseases.

3. Other causes of arthritis in children.

4. Chronic kidney disease.

5. Chronic liver disease.

All patients were subjected to full history, clinical examination, laboratory investigations as complete blood picture (CBC), ESR, CRP, RF, kidney and liver function tests, anti-CCP and anti-MCV. In both control and patient groups, $2 \mathrm{ml}$ of 
venous blood were taken in plain tube and left to clot at room temperature for 20 minutes, then centrifuged, and the serum was separated and stored at $\left(-20^{\circ} \mathrm{c}\right)$ until assessed for anti-CCP and anti-MCV using ELISA kit supplied by ORGENTEC Diagnostika GmbH, Germany.

\section{Statistical analysis:}

Data were analyzed using Statistical Package for the Social Sciences (SPSS) version 24. Quantitative data were expressed as median and interquartile range (IQR).

Mann-Whitney $\mathbf{U}$ test was used when comparing between two medians.

Probability (P-value): P-value $<0.05$ was considered significant.

\section{RESULTS}

As regards to anti-CCP and anti-MCV levels, there were highly statistically significant differences ( $\mathrm{p}$ value $<0.001)$ between patients and controls (Table 1).

Table (1): Comparison between studied groups as regard Anti-CCP and Anti-MCV

\begin{tabular}{|c|c|c|c|c|}
\hline \multicolumn{2}{|c|}{$\begin{array}{ll}\text { Parameters } & \text { Groups } \\
\end{array}$} & $\begin{array}{l}\text { Patients } \\
(\mathrm{N}=70)\end{array}$ & $\begin{array}{l}\text { Control } \\
(\mathrm{N}=20)\end{array}$ & P-value \\
\hline \multirow{2}{*}{ Anti-CCP(U/ml) } & Median & 57.4 & 2.75 & \multirow{2}{*}{$<0.001$} \\
\hline & IQR & $3.8-142.25$ & $1.72-4.27$ & \\
\hline \multirow{2}{*}{$\operatorname{Anti-MCV}(\mathrm{U} / \mathrm{ml})$} & Median & 173.3 & 7.05 & \multirow{2}{*}{$<0.001$} \\
\hline & IQR & $13.07-418.8$ & $4.75-12.9$ & \\
\hline
\end{tabular}

N: number, P_value: Probability value, SD: Standard deviation.

\section{DISCUSSION}

As regard serum anti-CCP \& anti$\mathrm{MCV}$, there were highly statistically significant differences between patients and controls.

The present study showed $65.7 \%$ abnormally high anti-CCP \& anti-MCV levels for patients $(10$ out of 13 polyarticular RF-positive, 16 out of 22 polyarticular RF-negative and 20 out of 35 oligoarticular), while $34.3 \%$ of patients show normal anti-CCP \& anti-MCV levels.

The results of this study were matched with that of Ahn and Kim (2019) who reported that anti-CCP can provide additional help for diagnosis of JIA with its high specificity. The advantage of this study is that included large number of participants (295 JIA patients and 165 controls). Also, long duration of follow up of patients is another advantage where the study was done in the period from 2004 to 2018. Lipinska et al. (2016) concluded that anti-MCV as well as anti-CCP antibodies may be helpful in the diagnosis of JIA, especially in the early course of the disease. In our study, and in agreement with previous study, anti-MCV and antiCCP positive patients with polyarticular type of onset more than anti-MCV and anti-CCP positive patients demonstrated oligoarthritis. Spârchez et al. (2016) reported that investigating anti-CCP 
should clearly be taken into consideration even among patients with JIA subtypes other than RF-positive polyarthritis. In agreement with our study, this study offer additional information regarding the potential role of anti-CCP particularly among patients with JIA subtypes other than RF-positive polyarthritis. El-Sayed et al. (2012) reported that measurement of serum anti MCV antibody level holds promise as a diagnostic tool in JRA. Tebo et al. (2012) reported that children with positive ACPA but negative RF are frequent, and may define a distinct subset of children with JIA. ACPA testing should be included in the classification of JIA.

On the other hand, Hamooda et al. (2016) reported that Anti-CCP could be utilized as a valuable marker in the polyarticular RF positive form of JIA only. This may be due to polyarticular RFpositive JIA is phenotypically similar to rheumatoid arthritis in adults. The difference between the current study and the study done by Hamooda et al. (2016) was that in the number of patients. Moreover, they included all subtypes of JIA, while our study included polyarticular and oligoarticular subtypes only.

\section{REFERENCES}

1. Ahn JG and Kim KN. (2019): Diagnostic value of anti-cyclic citrullinated peptide antibodies for Juvenile idiopathic arthritis in Korea. Ann. Rheum. Dis., 78(2):3156-3161.

2. Bandana $K$, Pawan $K$ and Radha KP. (2017): Evaluation of Anti-Cyclic Citrullinated Peptide Autoantibodies and $\mathrm{C}$ - reactive protein in Common Autoimmune Skin Diseases with and without Arthritis. J Clin Diagn Res., 11(7):6-8.

3. El-Sayed SS, Awaad KS, Mahmoud NH and Harraz KM. (2012): The diagnostic and monitoring value of serum anti-mutated citrullinated vimentin antibodies (anti-MCV) in juvenile rheumatoid arthritis. Egypt J. Pediatr. Allergy Immunol., 10(2):7580.

4. Foeldvari I. (2015): Ocular Involvement in Juvenile Idiopathic Arthritis: Classification and Treatment. Clin. Rev. Allergy Immunol., 49(3):271-7.

5. Giancane G, Consolaro A, Lanni S, Davi S, Schiappapietra B and Ravelli A. (2016): Juvenile Idiopathic Arthritis: Diagnosis and Treatment. Rheumatol. Ther., 3:187-207.

6. Hamooda M, Fouad H, Galal N, Sewelam N and Megahed D. (2016): Anti-cyclic citrullinated peptide antibodies in children with Juvenile Idiopathic Arthritis. Electronic Physician, 8(9): 2897-2903.

7. Joanna L, Stanislawa L, Marek K and Elzbieta S. (2016): Anti-MCV and anti-CCP antibodies-diagnostic and prognostic value in children with juvenile idiopathic arthritis. Clin. Rheumatol., 35:2699-2706.

8. Lipinska J, Lipinska S, Kasielski M and Smolewska E. (2016): Anti-MCV and anti-CCP antibodies-diagnostic and prognostic value in children with juvenile idiopathic arthritis. Clin. Rheumatol., 35:2699-2706.

9. Musaelyan A, Lapin S, Nazarov V, Tkachenko O, Gilburd B, Mazing A, 
Mikhailova $L$ and Shoenfeld Y. (2018): Vimentin as antigenic target in autoimmunity: A comprehensive review. Autoimmunity Reviews, 17:926-934.

10. Spârchez M, Miu N, Bolba C, Iancu M, Spârchez $Z$ and Rednic S. (2016): Evaluation of anti-cyclic citrullinated peptide antibodies may be beneficial in RF-negative juvenile idiopathic arthritis patients. Clin. Rheumatol., 35:601-607.

11. Tebo AE, Jaskowski T, Davis KW, Whiting A, Clifford B and Zeft
A. (2012): Profiling anti-cyclic citrullinated peptide antibodies in patients with juvenile idiopathic arthritis. Pediatr. Rheumatol. Online J., 10(1):29-34.

12. Willis VC, Banda NK, Cordova KN, Chandra PE, Robinson WH and Cooper DC. (2017): Protein arginine deiminase 4 inhibition is sufficient for the amelioration of collagen-induced arthritis. Clin. Exp. Immunol., 188:263-274. 
مقارنة الأجسام المضادة للبييتيد السبترولينى الحلقى

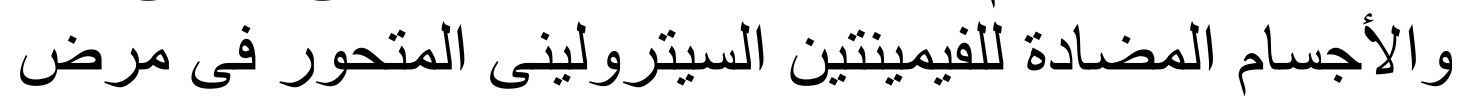
التهاب المفاصل الصبيانى مجهول السبب لفئرون

محمد عدلى خضرى زيدان، أحمد محمد عبدالرحمن طاحون، طارق عبدالكريم

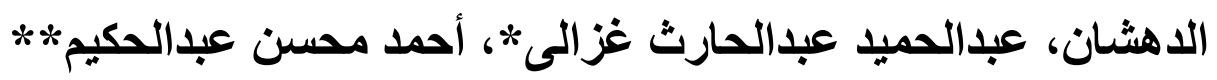

أقسام الباثولوجيا الإكلينيكية, الروماتيزم والطب الطبيعى والأطفال، كلية الطب، جامعة الأزهر

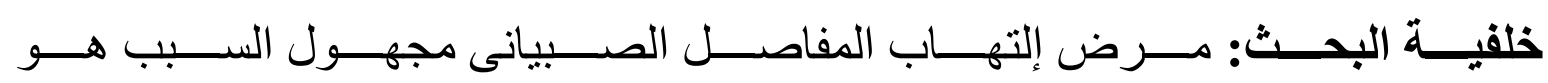

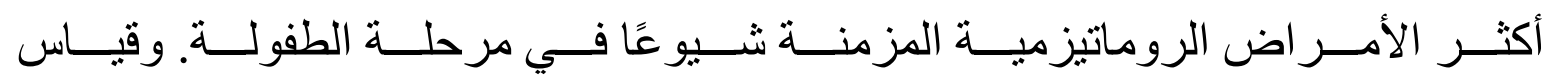

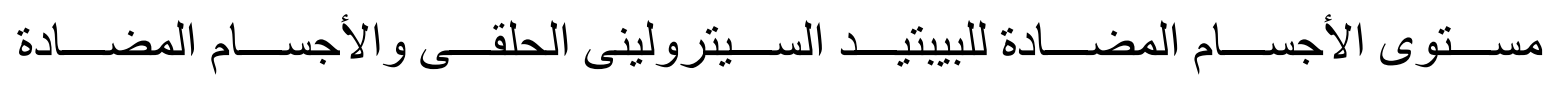

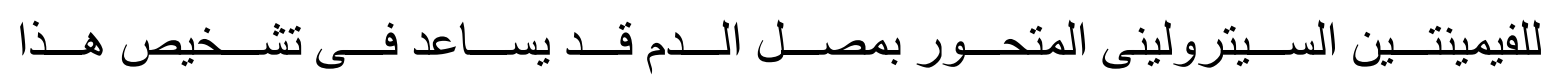

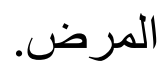

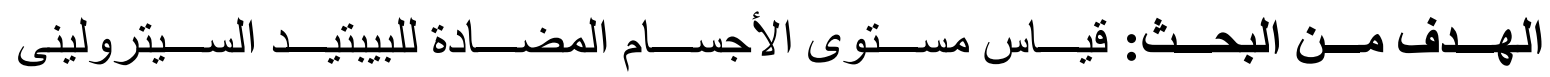

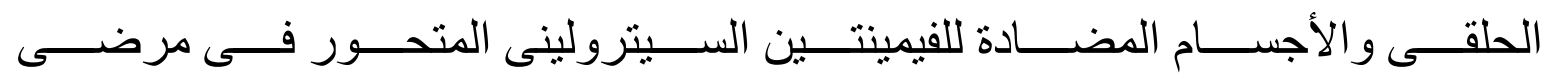

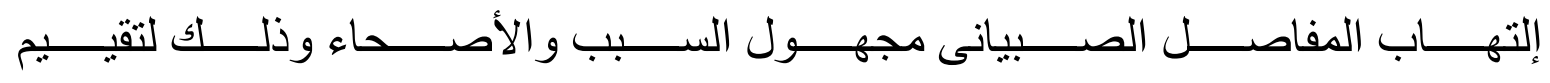

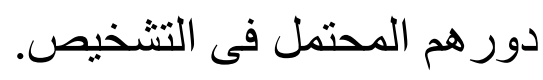

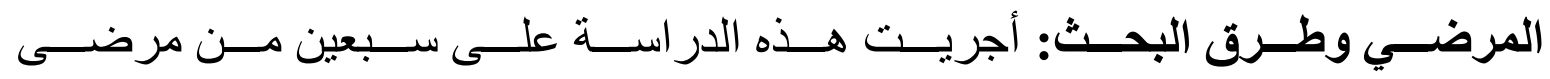

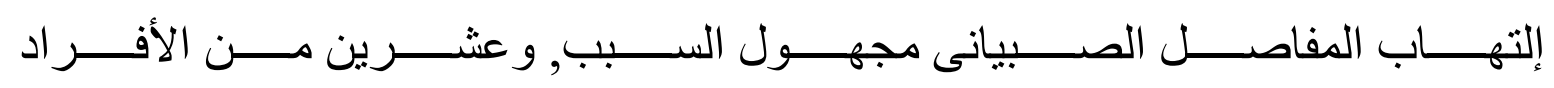

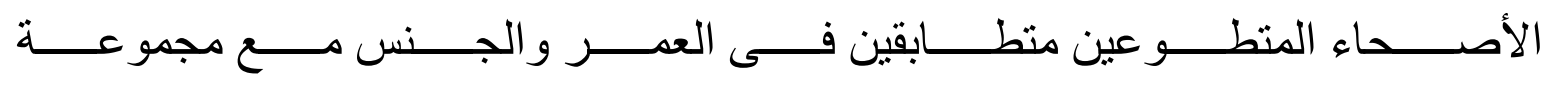

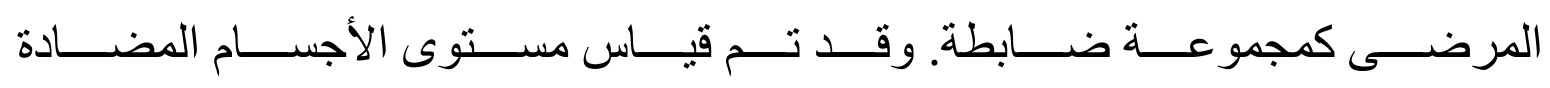

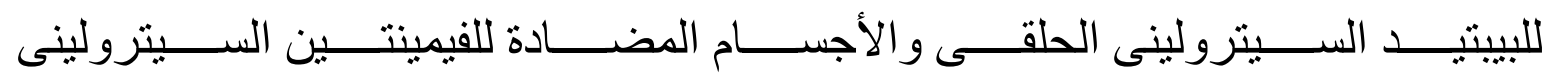

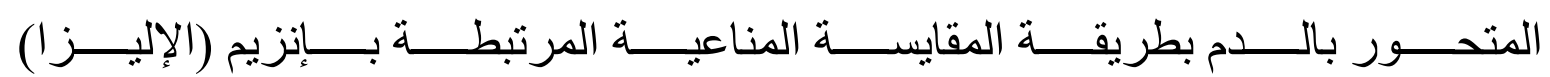

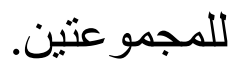




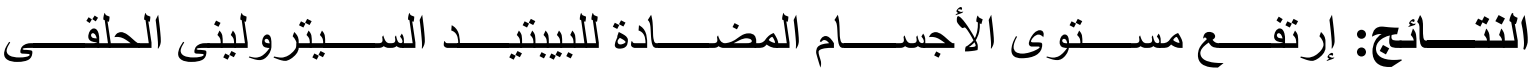

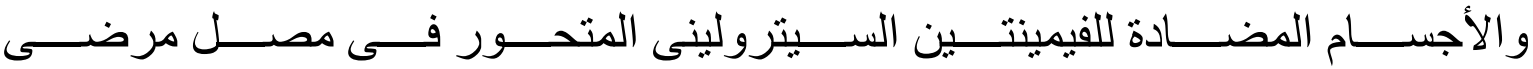

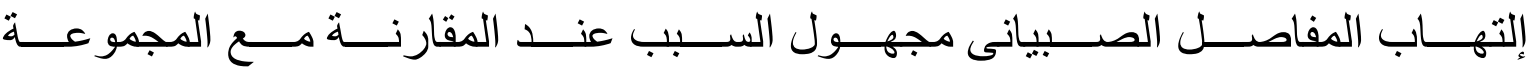
الضابطة مع وجود إختلاف ذو دلالة إحصائية.

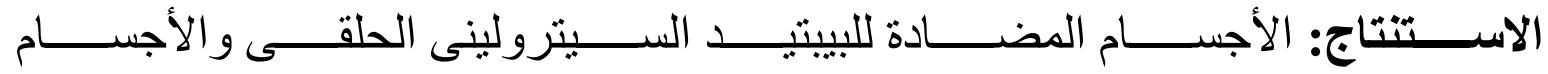

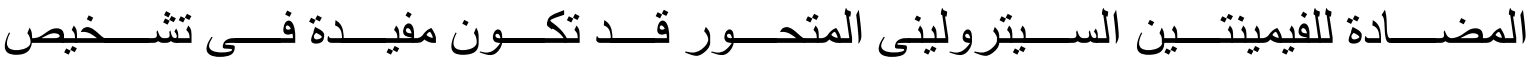

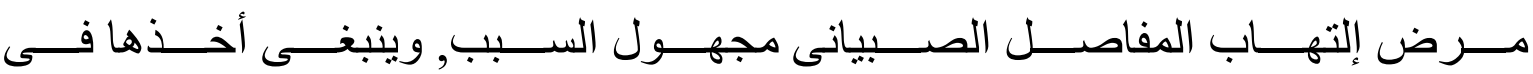

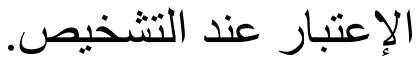

